\title{
CROSSING ALONE THE MEDITERRANEAN SEA. SOME CRITICAL ISSUES ABOUT UNACCOMPANIED MINORS IN EUROPE
}

\author{
Cruzando sozinhos o mar Mediterrâneo. Algumas questões críticas \\ sobre os menores não acompanhados na Europa
}

\author{
Giovanni Giulio Valtolina* \\ Marina $D^{\prime}$ Odorico*
}

\begin{abstract}
Despite the increasing social impact of unaccompanied migrant minors (UAMs) in many European Union (EU) member states, EU regulations on UAMs are still inadequate and the necessary protection measures are thus insufficient. More specifically, the "best interest of the child", stated in a large number of international documents, may not be properly guaranteed. In addition, there is often a discrepancy between the rights of migrant children, according to the international legislation, and the actual protection they receive. Moreover, despite the declared aim of reaching a common standard of reception and inclusion, policies and practices across Europe are still very different. The paper attempts to highlight and discuss some critical issues regarding UAMs in Europe. Over and beyond the need for the EU to develop a common framework, greater efforts should be made in order to improve inclusion of UAMs, especially to ensure the management of the phenomenon beyond the current emergency.
\end{abstract}

Keywords: migration, unaccompanied minors, European Union, children rights.

Resumo. Apesar do crescente impacto social dos menores migrantes não acompanhados (UAMs) em muitos Estados-Membros da União Europeia (UE), os regulamentos da UE sobre UAMs ainda são inadequados e as medidas de proteção necessárias insuficientes. Mais especificamente, o "o interesse superior da criança", atestado em uma grande quantidade de documentos internacionais, pode não estar devidamente garantido. Além disso, muitas vezes há uma discrepância entre os direitos das crianças

* Catholic University of the Sacred Heart. Milan, Italy.

** ISMU (Initiatives and Studies on Multiethnicity) Foundation. Milan, Italy. 
migrantes, de acordo com a legislação internacional, e a proteção real que recebem. Ademais, apesar do objetivo declarado de alcançar um padrão comum de acolhimento e inclusão, políticas e práticas em toda a Europa são ainda muito diferentes. O artigo tenta destacar e discutir algumas questões críticas relacionadas aos UAMs na Europa. Além da necessidade da UE desenvolver um quadro comum, maiores esforços deverão ser feitos para melhorar a inclusão dos UAMs, especialmente para garantir a gestão do fenômeno para além da emergência atual.

Palavras-chave: migração, menores não acompanhados, União Europeia, direitos das crianças.

The most recent data regarding unaccompanied immigrant minors (UAMs) in Europe shows that this phenomenon has become, in recent years, a steady component of migration flows to Europe, and is made up mostly of minors escaping from warzones. They come to Europe for different reasons, very often pushed by their own families and frequently in order to reach relatives already settled in EU countries and begin a better life. Because they travel without a family protection network, UAMs are more fragile and at greater risk of exploitation and smuggling. For this reason, several UE laws focus on them.

Despite the increasing social impact of the UAMs in many UE Member States, public opinion doesn't seem to have a specific attitude towards unaccompanied minors, identifying them prevalently as "children alone". Hence, their social representation does not specifically influence social behaviour and the negotiation of social identities.

Generally speaking, one - or more - of these four key reasons push these minors to leave their home country: economic motivations; reunification with a family member; education; joining a Diaspora community. Given the diversity of these factors, the universe of the UAMs is made up of different subgroups. A first difference is between asylum seeking and non-asylum seeking minors. In the subgroup of non-asylum seeking minors, however, we can still identify several different groups, such as victims of trafficking or undocumented minors. These are minors without a valid residence permit, who live outside any system of state support (including the asylum system). Usually unaccompanied minors are undocumented even before they come in contact with State services, and may have entered Europe irregularly and independently. In other cases, they may become undocumented if they lose contact with social services. Undocumented children are a multifaceted group, who often change status during the course of their childhood.

Public opinion, identifying UAMs as a homogeneous group of children, misses the heterogeneity of this group and the many issues raised by UAMs. 
The phenomenon of UAMs is a multifaceted issue, which cannot be addressed using a single approach. Typically represented as small children without any family link in the host country, UAMs are, on the contrary, a mixed group with specific features and different needs, which must have acknowledged and dealt with ${ }^{1}$.

As one of the most vulnerable categories in the complex scenario of contemporary human mobility at the global level, UAMs pose a challenge to EU countries and their ability to really guarantee the fundamental rights of the child and support the weakest members of society ${ }^{2}$.

According to the 2017 UNHCR report "Mixed Migration Trends in Libya: Changing Dynamics and Protection Challenges"3 about the change of the migrant flows and the condition of refugees, the number of migrants crossing the Mediterranean Sea is increasing, mostly from West Africa, so intensifying the danger for who wants to reach Europe. The UNHCR report highlights as half of all migrants and refugees traveling to Libya believe that they will find a job in that country, but end up having to flee to Europe from a situation of instability, insecurity, economic hardship, violence and abuse. The study has collected qualitative data in Libya, Chad, Niger, Tunisia, Algeria and Italy between October and December 2016. According to the report, in recent years the number of people taking advantage of the Mediterranean route has increased and will continue to grow. The route to Libya is considered the most commonly used, and even the deadliest. The study even shows how the profiles and nationalities of migrants who reach the country have changed in recent years, with a decrease in people from East Africa and an increase in Westerners, which now account for more than half of arrivals in Europe through the Mediterranean from Libya to Italy (over 100,000 in 2016). Refugees and migrants in Libya are mainly young men $(80 \%)$ and travel alone on average ( $72 \%)$. Women are often victims of trafficking and the number of unaccompanied minors is increasing, and today it represents $14 \%$ of arrivals in Europe through the Mediterranean.

Migrants in Libya tend to have a low level of study, with $49 \%$ absent or little education. Migrants from neighbouring Libya countries such as Chad, Niger, Sudan, Egypt and Tunisia travel mainly for economic reasons. Even migrants from West Africa travel mainly for economic reasons but there are also victims of trafficking and others who need protection. Those coming from East Africa emigrate for political persecution, conflicts and poverty.

\footnotetext{
VALTOLINA, Giovanni Giulio. Unaccompanied Minors in Italy.

ZANFRINI Laura. How Europe can Benefit from Immigration-Related "Diversity".

3 UNHCR. Mixed Migration Trends in Libya: Changing Dynamics and Protection Challenges.
} 
Other nationalities like Syrians, Iraqis, Palestinians, flee for violence and seek a life opportunity.

Among the main novelties of recent years, the UNHCR report emphasises that transit routes and hubs to Libya have changed and that people no longer travel to the northeast of the country. Migrants are increasingly less willing to stay in Libya and do not stop in cities for more than a few weeks, particularly in the south of the country. The report also highlights how the traffickers' industry has grown significantly, with transnational and professional development organizations. Armed groups are increasingly involved in the world of traffickers and travel prices have generally gone up. In any case, migrants passing to Libya are more vulnerable, and support and security services have declined. In recent years, migrants have become less and less visible, especially for those who offer "organized travel" under the control of traffickers. The report points out, however, that some aspects have not changed, such as entry points in the country. Finally, the UNHCR highlights the importance of providing direct assistance, particularly in the key hubs of the Southern Libya and to unaccompanied minors, in addition to carrying out border monitoring, migration risk information campaigns and greater awareness and collaboration of the Libyan authorities.

After presenting some data about the UAMs arrived in Italy through the Mediterranean Sea and the EU current framework on the issue, the aim of this paper is to provide a preliminary review of some critical issues dealing with UAMs in EU Member States.

\section{Unaccompanied Minors: numbers and countries of origin}

Although the presence of foreign minors in Italy appears to be structural and supported by in-direct interventions to facilitate integration processes, special attention is paid to the segment of children arriving in Italy without parents and that in recent years has recorded a significant increase and to which particular attention be given, having regard to the condition of vulnerability in which they live. In order to manage the phenomenon of UAMs, it is essential for policy makers to have a picture - and a truly accurate one, at that - of the presence in the EU and in the single Member States. Admittedly, this is a tough challenge. Identifying the number of UAMs in the EU is quite difficult because they are a very heterogeneous group, as we have already pointed out. To define them comprehensively, one should include: minors without EU citizenships, present in a Member State without parents or other legal guardians, and not applying for asylum; minors with an EU Member State citizenship, but identified not in their home country, without parents or other legal guardians; minors who have applied for international protection and are considered by the State's national authority to be unaccompanied minors. 
Moreover, a great number of UAMs, identified and hosted in specific locations by national authorities, end up missing or run away from reception facilities, making it impossible to know where they really are - in which country - and what they are doing. Mostly, this latter group is trying to reach relatives in an EU country, but it is not unusual for them to become victims of trafficking.

The fact that, in each EU member State, UAMs are managed by different national institutions makes it impossible to get a clear quantitative picture of their number. Indeed, many UAMs move through invisible routes, much like adult illegal migrants. The only official data we have refers to the number of UAMs applying for international protection, on the one hand, and to UAMs with a regular permit as minors, on the other, whereas we are missing real data about UAMs with EU citizenships moving across Europe, victims of trafficking and those travelling illegally.

In recent years, however, things are changed. Eurostat ${ }^{4}$, as well as data on UAMs seeking asylum, started also to collect data regarding non-asylum seeking UAMs, like the European Migration Network ${ }^{5}$.

On September 30, 2017, according to the Ministry of the Labour and Social Policies ${ }^{6}$, UAMs registered in Italy were 18.491, 17.211 males $(93,1 \%)$ e 1.280 females (6,9\%). About the age, this was the distribution:

Tab. 1. UAMs registered in Italy. August $30^{\text {th }}, 2017$

\begin{tabular}{l|c|c}
\hline Age & & $\%$ \\
\hline $15-17$ years & 17.178 & 92,9 \\
\hline $7-14$ years & 1.204 & 6,5 \\
\hline $0-6$ years & 109 & 0,6 \\
\hline Total & 18.491 & 100 \\
\hline
\end{tabular}

Source: Italian Ministry of Labour and Social Policies, 2017.

The country of origin of these minors were:

${ }_{4}$ Eurostat (ec.europa.eu/eurostat) is the statistical office of the European Union. It provides the European Union with statistics at European level that enable comparisons between countries and regions. Its mission is to be the leading provider of high quality statistics on Europe.

5 The European Migration Network (EMN; www.emn.ie) is a network of the European Commission that provides policy makers - at EU and Member States level - and the general public up-to-date, reliable and comparable information on migration and asylum topics.

6 Cf. <http://www.lavoro.gov.it/temi-e-priorita/immigrazione/focus-on/minori-stranieri/Docum ents/Report-MSNA-mese-settembre-30092017.pdf>. 
Tab. 2. UAMs country of origin. August $30^{\text {th }}, 2017$

\begin{tabular}{l|c|c}
\hline COUNTRY OF ORIGIN & $\mathbf{n .}$ & $\%$ \\
\hline Gambia & 2.456 & 13,3 \\
\hline Egypt & 1.804 & 9,8 \\
\hline Guinea & 1.791 & 9,7 \\
\hline Albania & 1.647 & 8,9 \\
\hline Nigeria & 1.434 & 7,8 \\
\hline Ivory Coast & 1.406 & 7,6 \\
\hline Eritrea & 1.322 & 7,1 \\
\hline Mail & 1.062 & 5,7 \\
\hline Senegal & 997 & 5,4 \\
\hline Bangladesh & 959 & 5,2 \\
\hline Somalia & 752 & 4,1 \\
\hline Pakistan & 383 & 2,1 \\
\hline Afghanistan & 350 & 1,9 \\
\hline Ghana & 345 & 1,9 \\
\hline Kosovo & 291 & 1,6 \\
\hline Morocco & 258 & 1,4 \\
\hline Sudan & 155 & 0,8 \\
\hline More & 1.079 & 6,4 \\
\hline TOTAL & 18.491 & 100 \\
\hline
\end{tabular}

Source: Italian Ministry of Labour and Social Policies, 2017.

But a relevant number of these UAMs goes missing, after registered and collocated in a community or in a foster family, they left. On September 30, 5.463 UAMs were missing. Usually they leave because of the need to earn money to send to family at home, since they run into debt to get money to pay the migration of the young son. About it, it has to be said that often, to get money, they commit crime or work for criminal organization, selling drugs or coming robbery. Some other UAMs leave to reach some relatives already migrated in some European countries, mostly in the North Europe.

\section{UAMs crossing Mediterranean Sea}

As for Italy, in the first six months of 2017, through the Mediterranean have come 11,406 UAMs. The forecast is that by the end of 2017, approximately 23 thousand UAMs arrive in Italy without family and without reference adults at their side, a number likely to be similar to that of 2016 . 
Fig. 1. UAMs landed in Italy by rescue ships (2014-2017)

Minori stranieri non accompagnati sbarcati in Italia. Anni 2014-2017

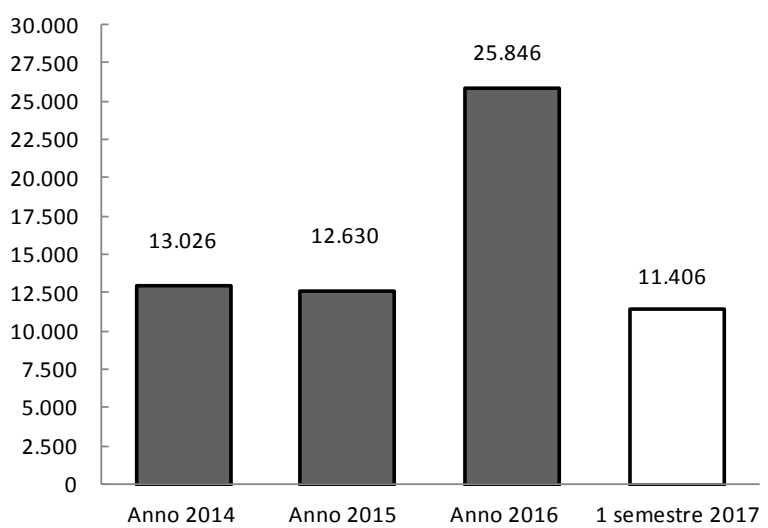

Source: Italian Ministry of Interior, 2017.

But not only the number of UAMs grew; also the percentage of UAMs of the total number of migrants has increased considerably, from $7.7 \%$ in 2014 to $14.2 \%$ in 2016, compared to a reduction in the number of minors migrating with their family: from $7.7 \%$ in 2014 to $1.3 \%$ in 2016 .

In the 2017, the monthly data highlights an upward trend, with a peak in May and June, when 6.216 UAMs landed on the Italian coasts by the rescue boats: an average of 102 landings per day. To date, they account for about 13\% of arrivals in Italy by Mediterranean.

Tab. 3. Arrivals in Italy by Mediterranean 2015-2017

\begin{tabular}{cc|c|c|c}
\hline & Total arrivals & UAMs (A.V.) & UAMs (\%) \\
\hline $\mathbf{2 0 1 5}$ & 153.842 & 12.360 & 8,0 \\
\hline $\mathbf{2 0 1 6}$ & 181.436 & 25.846 & 14,2 \\
\hline $\mathbf{2 0 1 7}$ & & & \\
\hline \multicolumn{2}{|c|}{} & & & 17,9 \\
\hline \multicolumn{2}{c|}{ January } & 4.467 & 798 & 12,0 \\
\hline \multicolumn{2}{c|}{ February } & 8.972 & 1.077 & 14,9 \\
\hline \multicolumn{2}{|c|}{ March } & 10.853 & 1.616 & 13,2 \\
\hline \multicolumn{2}{|c|}{ April } & 12.920 & 1.699 & 13,6 \\
\hline \multicolumn{2}{|c|}{ May } & 23.016 & 3.122 & 13,2 \\
\hline
\end{tabular}

Source: ISMU on UNHCR and Italian Ministry of Interior data, 2017. 
The percentage of unaccompanied minors on the total number of foreign immigrant children has increased in recent years: in $2014,49 \%$ of the 26,000 young people arrived in Italy that year; in 2015 they accounted for $75 \%$ of the 16,500 children who landed, while in 2016 they were $91.6 \%$ and in the first half of 2017 93.2\%, witnessing a predominantly individual migration of almost adult young people, mainly from the African continent.

Tab. 4. Minors landed in Italy by Mediterranean 2015-2017

\begin{tabular}{|c|c|c|c|c|c|c|}
\hline & 2015 & 2016 & $\begin{array}{c}2017 \\
\text { (30th June) }\end{array}$ & 2015 (\%) & 2016 (\%) & $\begin{array}{c}2017 \text { (\%) } \\
\text { (30th June) }\end{array}$ \\
\hline \multicolumn{7}{|l|}{ Minors: } \\
\hline - Accompanied & 4.118 & 2.377 & 833 & $25,0 \%$ & $8,4 \%$ & $6,8 \%$ \\
\hline - UAMs & 12.360 & 25.846 & 11.406 & $75,0 \%$ & $91,6 \%$ & $93,2 \%$ \\
\hline Total & 16.478 & 28.223 & 12.239 & $100,0 \%$ & $100,0 \%$ & $100,0 \%$ \\
\hline
\end{tabular}

Source: ISMU on UNHCR data.

This distinguishes the Italian situation from the Greek one, which is mainly characterized by a migration of families coming from the Middle East (Syria, Afghanistan, Iraq): at the end of July, data for Greece indicate that landings of minors with their family was $38 \%$ of all the landed migrants (in Italy was $16 \%$ ) and women landings equal to $20 \%$ (in Italy they were $13.6 \%$ ).

Fig. 2. Family landings in Italy and Greece (January-July 2017)

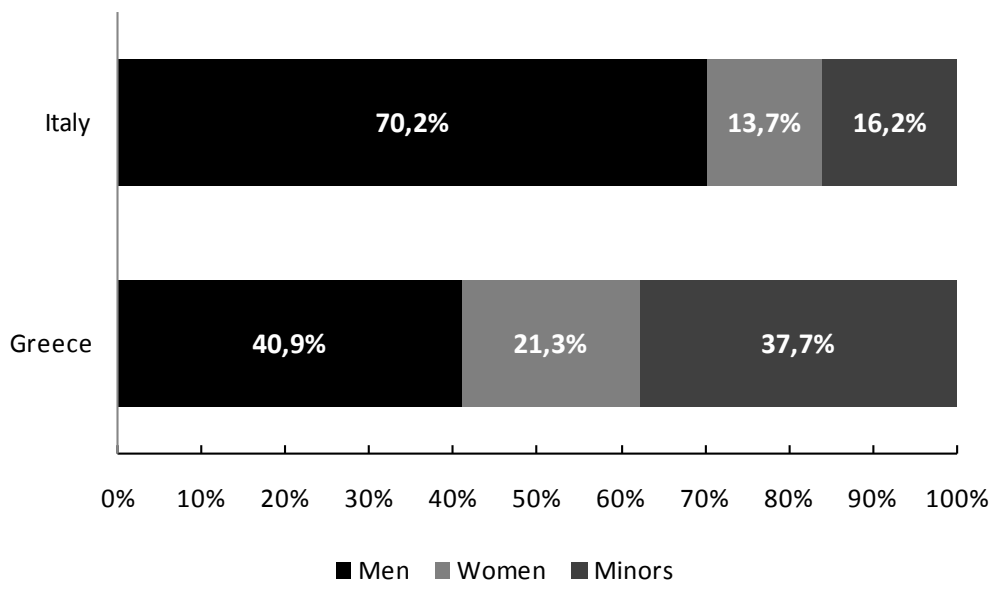

Source: ISMU on UNHCR data.

The nationality of minors arriving in Italy is predominantly African: in the first place there are young Gambians (1,902, 13.9\%), followed by Eritreans, 
Egyptians and Nigerians. The data reveals that among Egyptians who arrived in Italy in 2016 - men, women, and minors -, UAMs make up 59\% of all immigrants from Egypt.

\section{The European and Italian law on UAMs}

The European Union dealt with the issue of UAMs in the framework of its agenda on immigration. The Stockholm Programme on Justice, Freedom and Security, for 2010-2014, dedicated an explicit section to these minors as a "particularly vulnerable group which requires special attention and dedicated responses, especially in the case of minors at risk"7. The core topics are: the fight against trafficking of minors, the assessment of their age, the exchange of information and best practices, the identification and the tracing of their families, cooperation with their home countries.

In this framework, the European Commission ratified the "Action Plan on Unaccompanied Minors 2010-2014"8, aimed at developing adequate instruments and policies to guarantee the protection of UAMs and the identification of durable solutions across all EU Member States. The Action Plan tried to outline a shared approach on this topic, primarily based on three actions: prevention of trafficking and of at-risk migration; reception and procedural guarantees across all of the EU; the search for durable solutions. The Action Plan confirmed some basic principles, including the best interest of minors as the main consideration for any measure involving UAMs ${ }^{9}$. The efforts of all the EU members States are directed towards the possibility for UAMs to grow in their home countries. At any rate, the European Commission confirmed the right of any UAM to get specific reception measures and procedural guarantees, including the assignment of a guardian or legal representative. The Action Plan also states that UAMs should always be hosted in suitable facilities and that imprisonment - although justified in exceptional cases - should represent the last option and be adopted only for the shortest period of time, always considering as fundamental the best interest of the minor.

The European Commission also sets a deadline for procedures concerning UAMs, clarifying that the decision on the future of each minor must be adopted as rapidly as possible, and preferably within six months. Regarding this issue, particularly significant is the European Parliament's resolution of September 12, 2013, regarding the status quo of UAMs in the $\mathrm{EU}^{10}$. The resolution urged the

EUROPEAN UNION. Stockholm Program "An open and secure Europe serving and protecting the citizens".

8 EUROPEAN COMMISSION. Communication 6 May 2010 COM(2010)213.

9 BIONDI DAL MONTE, Francesca. The system of reception of unaccompanied minors: legal profiles and integration policies.

${ }^{10}$ EUROPEAN PARLIAMENT. The situation of unaccompanied minors in the EU. 
Commission and Member States to focus on safeguarding of the fundamental rights of the child, considered that the existing measures in the EU were not sufficient to guarantee complete protection of UAMs. Likewise, the European Parliament's suggestion that the European Commission prepare guidelines, summarizing the legislative aspects of the matter and aimed at simplifying their application by Member States, and to strengthen the protection of unaccompanied minors, was equally important. The Parliament also requested the Commission to draft a set of binding guidelines for Member States; such guidelines should be inspired by best practices and aim to shape common approaches, as well as detailing any phase of the process. The issue of financial resources was also highlighted in the European Parliament suggestion, stressing the inadequacy of funds presently allocated for this issue and inviting the Commission to assign specific funds to UAMs, both within the new European "Asylum and Migration" Fund - in order to create sustainable actions for the protection of minors - in the framework of the European Social Fund - mainly in order to support specific European countries. The Parliament's suggestion highlighted the need to provide appropriate, long-term financing for programs, aimed at identifying UAMs, hosting them adequately, appointing guardians, tracing their families, and granting them new accommodation and social reintegration.

On May 6, 2017, new legislation for the protection of UAMs entered into effect in Italy (Law No. 47 of April 7, 2017). The new Law introduces several amendments to Legislative Decree No. 286 of 1998 on immigration and the status of foreigners in Italy, and protects foreign minors who enter Italy without an adult by recognizing the same rights for them that Italian and European Union minors have, due to their particular situation of vulnerability (Law No. 47, art. 1). For legal purposes, a UAM is defined as a minor who is not an Italian or EU citizen, who for whatever reason is found in Italian territory or is subject to Italian jurisdiction, and who lacks the assistance or representation of his parents or other adults who would be responsible for him according to Italian legislation (art. 2). The new legislation creates the National Information System for UAMs under the Ministry of Labour and Social Policies (art. 9). A special folder containing pertinent information for each minor is maintained in this system (art. 9). Law No. 47 also declares the intention of the Italian Republic to further international cooperation efforts underway in order to protect UAMs who might enter the national territory (art. 20). Other highlights of the Law are:

a) the prohibition of refoulement and Granting of Residence Permits. The amendments introduced by Law No. 47 specify that UAMs may never be rejected at the border, prohibiting refoulement and expulsion (art. 3). In these situations, the local police commissioner must grant a residence permit to the foreign minor (art. 10). Such a permit must also be granted to any UAMs 14 
years of age or younger based on family-reunion grounds, or to those minors subjected to foster care of an Italian citizen with whom they live, or to minors older than 14 years of age and in the custody of and living with foreigners who are legal residents of Italy (art. 10). In exceptional cases, when the expulsion of a foreign minor is ordered by the juvenile court, such a measure may be adopted only if it does not cause a risk of serious damage to the minor (art. 3).

b) the identification of UAMs and determination of their status. When a UAM first comes into contact with a government official, an inquiry must be made to determine the personal and family history of the minor in order to adopt the best protective measures (art. 5). A "cultural mediator" must be present in the interviews with the minor. A "cultural mediator" is a person with a professional degree granted by an institution of higher education in Italy, whose services are used in different contexts, including by a juvenile court to assist in the proceedings involving foreign persons. The public security authorities, psychologists, social worker, aided by cultural mediators, and in the presence of the permanent or temporary guardian assigned to the minor, interview the minor to determine his or her identity, but only after any immediately necessary humanitarian assistance is provided to the minor (art. 5). Local government agencies must provide first aid and hospitality facilities especially dedicated to UAMs (art. 4). Diplomatic and consular authorities collaborate with the other responsible officials to determine the age of the minor, but only if there is no risk that the establishment of age could result in persecution of the minor, or when the minor refuses the assistance of diplomatic and consular authorities in the age determination process. If necessary, at the request of the Attorney General of the Republic, the local juvenile court will establish the age of the minor (art. 5);

c) Family Investigation and Foster Placement or Repatriation. Several government agencies join in conducting an investigation to establish whether the minor has appropriate family members who may assume the care of the minor; only if there is no willing and able family member is the minor placed in a community centre or with foster families (art. 6). Local government entities may promote the designation of foster families or a community to whom juvenile courts may entrust the care of UAMs (art. 7). The local juvenile court will order the assisted and voluntary repatriation of a foreign unaccompanied minor when reunion of the child with his or her family in the country of origin or in a third country is in the best interests of the child (art. 8);

d) Rights of UAMs; UAMs found in Italian territory have the right to health and education, even before they are issued a residence permit (art. 14). The intervention of cultural mediators is required in all decisions concerning the minors' health and education needs. UAMs also have the right to be heard in all judicial and administrative proceedings affecting them. Their consent is 
necessary for the intervention of non-governmental organizations dedicated to the assistance of vulnerable persons in legal procedures concerning them (art. 15). The minors have the right to appoint legal counsel whom they trust to handle judicial and administrative procedures involving them; funds for the payment of legal fees incurred by such minors in 2017 are provided for under the Law (art. 16). In addition, within 90 days from the entry into force of Law No. 47, a register of volunteer tutors must be created at all juvenile courts throughout Italy, among citizens selected and vetted by local governments, to teach the minors Italian and provide them with other necessary assistance and guidance (art. 11);

e) UAMs victim of trafficking; according to the new Law, particular attention must be paid by the respective authorities so that UAMs do not fall victim to human trafficking. If the minor has already fallen prey to human trafficking, he or she must receive adequate assistance from the respective authorities (art. 17).

\section{Some critical issues}

Using the evidences coming from a study carried out by ISMU foundation, about the condition of UAMs in Europe, it is possible to highlight some critical topic, involving UAMs reaching Europe. The study consisted in two parts: a review of the international literature on UAMs in Europe ${ }^{11}$ and a set of 25 interviews, with international stakeholder ${ }^{12}$. Generally speaking, these are the most important issues, emerging from the study:

- regarding the identification of border crossing UAMs, a key point is age assessment; since many UAMs cross borders without any identification documents or with documents that need to be checked for authenticity, the practices for age assessment are different across EU States, in terms of motives, methods and timing;

- creating collaborations among the different stakeholders involved in the reception and inclusion of UAMs;

- $\quad$ ensuring UAMs have access to education, through professional training and skills development; it is fundamental in order to support them in finding employment and becoming independent;

- having skilled, trained and dedicated staff, able to deal with UAMs appropriately (especially cultural mediators);

- endorsing the active involvement of UAMs in their route to integration, through specific measures aimed at fostering their empowerment;

- $\quad$ ensuring all UAMs benefit from the same level of protection; currently,

\footnotetext{
11 The full list of documents is available at: $<$ www.ismu.org/en/minors-and-family $>$.

12 Italy: 4 stakeholders; Belgium: 3; Netherlands: 2; France: 1; Greece: 1; Spain: 1; Germany: 1; International Organization for Migration (IOM): 1; European Commission: 1; European Council on Refugees and Exiles (ECRE): 1; Save the Children: 1.
} 
in EU member States, there is a clear gap between asylum seeking and non-asylum seeking minors, e.g., in terms of how fast a representative/ guardian is appointed;

- tackling the situation of UAMs who go missing or run away from reception facilities;

- accomplishing the obligations related to upholding the right to family unity, in particular family tracing, as indicated in EU documents;

- finding resources to obviate the budget cuts and the lack of financial support in most countries, which affect the development of actions for the integration of UAMs and hinder efforts aimed at the finding durable solutions;

- identifying the adequacy of reception facilities for UAMs; currently, in some Member States, UAMs seeking asylum seeking and those not seeking asylum are all hosted in similar facilities, whereas in other EU Member States they are allocated to different facilities. The types of facilities offered are also quite different: some countries have facilities specifically for children, others have a dedicated area within mainstream facilities, others still have opted for foster families;

- identifying "durable solutions" for UAMs, as stated in the Action Plan on Unaccompanied Minors 2010-2014; the creation of a National Action Plan, encompassing "durable solutions" for UAMs, is essential, especially given the fact that one is not currently in place in any EU Member States;

- highlighting the role of civil society in hosting and integrating UAMs;

- accompanying the change in status, once UAMs turn 18 years of age.

It has to be said that this last issue is widely acknowledged as one of the most important, because of the high number of UAMs currently living in the EU member States close the age of 18. For this reason, we are going to present the different practices adopted in different Member States, in order to shed light on the variety of arrangements currently practiced with regards UAMs' change of status. Given the different practices implemented across the EU, coordinated strategies and actions at the EU level are urgently needed.

\section{The transition to adulthood}

UAMs turning 18 face a transition in residence permit, depending on the host country ruling and on their migration status. Consequently, this may affect their access to various citizenship rights, such as employment and education. As well documented in the EMN Report ${ }^{13}$, if the UAM turning 18 is an Asylum Seeker in the EU, all EU States must allow him/her to legally remain

13 EUROPEAN MIGRATION NETWORK (EMN). Policies, practices and data on unaccompanied minors in the EU Member States and Norway. Synthesis Report: May 2015. 
in the country up to his/her application for international protection is being assessed. If the UAM has already been granted refugee status or another form of international protection, all Member States must ensure that she/he is issued with a long-term residence permit and can continue accessing the same rights as adult refugees or other migrants benefiting from international protection.

If the UAM turning 18 is not an Asylum Seeker, or if his/her application for international protection has been rejected, his/her position may radically change. In some States (Italy, Poland, United Kingdom, Belgium, Slovenia, Cyprus, Estonia, Norway, Lithuania) they are considered illegal residents and may be sent back to their home country. But if they have a valid reason to stay in the country - for example, if she/he is attending school or is employed-some States may issue a temporary residence permit for the duration of the pending obligations (Italy Germany, France, Poland, Luxembourg, Slovak Republic, Belgium, Estonia).

The situation is not the same in all the EU, because some Member States consider a set of exceptional circumstances. In the United Kingdom, for example, authorities take into account whether the UAM was a child or an adult at the time of trafficking, particularly with respect to the issue of consent and whether it would be safe or practical for the person to return to his/her home country. In Finland, victims of trafficking or individuals who do not receive international protection (or any other kind of residence permit) can on a case-by-case basis - be issued with a residence permit which precludes their removal as aliens. In the Czech Republic, a former UAM may apply for a permanent residence permit for humanitarian grounds or for any other special motive deemed worthy of consideration.

In general, in terms of accommodation arrangements and non-material reception conditions, some EU countries may consent former UAMs to stay in the same accommodation up to a certain age (e.g., 21 in Austria, Belgium, France and Sweden; 25 in Poland), if they are enrolled in an educational programme or are working, or if they are believed to be outstandingly exposed (United Kingdom, Luxembourg, Poland, Austria, Belgium, Czech Republic, Ireland, Sweden). On the contrary, in several countries (Austria, Belgium, Finland, Hungary, Ireland, Latvia, the Netherlands, Poland, Spain, Sweden, Norway), former UAMs are urged to move and change housing once they reach the age of 18. In most of these countries, former UAMs leave and are hosted in prearranged reception facilities for adults or in individual accommodation.

Within the EU, it is possible to find 2 different kind of measures implemented by Member States to support UAMs: procedures to support UAMs before turning 18 and procedures to support UAMs after their $18^{\text {th }}$ birthday. Regarding the former - procedures to support UAMs before the transition to 
adulthood - not many EU States have adopted measures to support UAMs. The most frequent practice is to move the UAM to a different accommodation, as is commonplace in France, Spain, Poland, Belgium, Finland and Latvia. Some countries have developed individual "post-18 programs", which are devised along with the UAM turning 18 years well before his/her birthday. One country where this takes place is Ireland, where a social worker starts to work on the post-18 programme with the single UAM already when she/he turns 16 . If a UAM is involved with the Social Service at age 16 or over, the programming starts after a suitable time has passed and the UAM is more comfortable in the new accommodation. A similar procedure is currently underway in the United Kingdom, where a personal Independent Reviewing Officer (IRO) is appointed for each UAM. This Officer is in charge of inspecting and assessing the personalized programme and for ensuring it cares for the wishes and the stances of the UAM. IROs are also required to guarantee that she/he understands her/his rights in order to access independent advocacy support. From age 16, moreover, UAMs must be allocated a Personal Adviser (PA), who is responsible for coordinating a plan and arranging the services she/he will access to receive support.

Likewise, other EU States support UAMs in the transition to adulthood through programs supporting their independence. For example, in the Czech Republic UAMs are prepared for independence approximately one year before turning 18. They have access to a lot of important information on their citizenship rights and assistance opportunities, are given key contacts (e.g. the guardian, the Employment Office, etc.), and their housing and employment possibilities are jointly assessed. In Finland, an "independence promotion programme" is created at least six months before the UAM turns 18. This plan consists of integration training, along with other services supporting social inclusion (i.e., dealing with authorities, looking for a job, renting a house, etc.).

Unlike the aforementioned countries, some others EU States, such as Belgium, coach non-asylum seeking UAMs in order to send them back to their home country after their $18^{\text {th }}$ birthday. The UAM's guardian, along with social workers, analyses the unlike options with the UAM - returning or remaining illegally - and the necessary measures are taken to prepare the UAM for their new status, including access to the voluntary return program, access to services for undocumented people, etc. The United Kingdom also gives support to UAMs who want to go back willingly, through the "Assisted Voluntary Return for Families and Children Programme".

Regarding the second measure - procedures to support UAMs after the transition to adulthood - many Member States in the EU are open mainly to UAMs who have been granted international protection. In Norway, for instance, once they turn 18, UAMs who have been granted asylum and have completed 
compulsory education go and live in cities where they go through a 2 years integration programme. They are given an integration coordinator, in order to help them work out everyday matters. All former UAMs participating in the integration programme receive a monthly grant which covers basic needs, such as rent, food, and clothes. Likewise, Lithuania has a similar integration programme for UAMs turning 18, but its duration is shorter, usually 12 months. Likewise, other EU countries, such as United Kingdom, Finland and Slovenia, have "post-18 programmes", both for Asylum Seekers and non-Asylum Seekers.

As aforementioned, turning 18 years of age and entering adulthood is a critical issue for UAMs as their status changes completely, forcing them to cope with new tasks they may not be equipped for. Hence, monitoring procedures which have been implemented in some EU countries, even though the application of such procedures noticeably differs among EU countries, is paramount. It is very urgent that a monitoring system be implemented in all EU countries, especially those, such as Italy, where the number of UAMs is particularly significant.

Finally, let us turn to a list of the major challenges related to UAMs' transition to adulthood, in the EU. The change of accommodation is universally considered as the main source of distress for UAMs. First of all, because moving to a different city or region means leaving school and the other established social networks. Furthermore, transferring to an adult accommodation centre is often a traumatic event for UAMs, given that the new context is remarkably different from the facilities they had previously experienced. Moving to individual accommodation can also be an overwhelming experience, because of the change from sharing a room with peers to living alone in an apartment. The end of institutional support and of the guardian's presence is also a challenge a UAM has to face.

UAMs who were victims of trafficking face some specific challenges. In Finland, for example, the State Authority believes that victims of trafficking need more time to be supported in order to choose a different type of life, in particular if they have been exposed unprotected to abuse for a long time. For these UAMs, the risk of disappearance and re-victimization is very high.

In conclusion, it is also important to point out the hard challenge faced by Member States in implementing monitoring systems for former UAMs, thus causing an excessive difference in services and support offered to UAMs and to their integration in the host country across EU.

\section{Concluding remarks}

A first important issue about UAMs in EU which has to be faced is that measures aimed at improving cooperative relationships among actors at all 
levels of governance would be more than welcome. The crucial point is that the more collaboration increases, the greater the benefit for UAMs, because this ensures that the "best interest of the child" is put first.

The literature review and the information gathered through the interviews conducted enable us to make the following recommendations:

- it is important to improve data collection methods, with full respect of data protection standards; data concerning UAMs' reception and inclusion should be collected at individual level in order to properly assess how processes occur and thus, potentially, to improve shortcomings;

- UAMs must always be treated, at all levels of governance, as holders of individual rights, right from the beginning and in consideration of their particular condition: they are minors and they are migrants; currently, they are minors who face the same situations of other migrants but without any support;

- ensuring that UAMs' rights are explicit in legislation and accessible in practice; this includes pursuing proactive measures to eliminate practical barriers, such as warranting equal access to all levels of education, health service, and shelter, regardless of residence status;

- operationalizing existing legal safeguards and procedural guarantees, such as the best interest of the child principle; advocacy activities could be used in order to reach this goal;

- evaluating enforcement rules and practices - arrest, detention and deportation - in order to assess the impact on child rights and rapidly redress individual rights violations. In some Member States if the law states that a minor has to be expelled, it rarely occurs; creating a situation whereby they stay in detention centres or live undocumented on the road, with no rights;

- implement measures and setting rules, taking into account the currently different social and legal contexts.

In conclusion, our analysis highlights that more efforts, in terms of activities and funds, should be made in order to improve the strategies of reception and inclusion of UAMs in Europe. It is mandatory for EU member States to provide the tools to face this situation beyond the emergency.

\section{References}

BIONDI DAL MONTE, Francesca. The system of reception of unaccompanied minors: legal profiles and integration policies. In VALTOLINA, Giovanni Giulio (ed.). Unaccompanied Minors in Italy. Milan: McGraw-Hill, 2014, p. 17-30.

EUROPEAN COMMISSION. Communication 6 May 2010 COM(2010)213. Available at: <https:// ec.europa.eu/antitrafficking/sites/antitrafficking/files/ action_plan_on_unaccompanied_minors_en_1.pdf $>$. 
EUROPEAN MIGRATION NETWORK (EMN). Policies, practices and data on unaccompanied minors in the EU Member States and Norway. Synthesis Report: May 2015. Brussels, 2015. Available at: <http:// ec.europa.eu/dgs/home-affairs/ what-we-do/networks/european_migration_network/reports/docs/ emn-studies/ emn_study_policies_practices_and_data_on_unaccompanied_minors_in_the eu_member_states_and_norway_synthesis_report_final_eu_2015.pdf $>$.

EUROPEAN PARLIAMENT. The situation of unaccompanied minors in the EU. European Parliament resolution of 12 September 2013 (2012/2263(INI). Available at: <http://www.europarl.europa.eu/sides /getDoc.do?pubRef=-//EP// TEXT+TA+P7-TA-2013-0387+0+DOC+XML+V0//EN > .

EUROPEAN UNION. Stockholm Program. An open and secure Europe serving and protecting the citizens (2010/C 115/01), paragraph 6.1.7. Available at: $<$ https://ec.europa.eu/antitrafficking/sites/antitrafficking /files/the_stockholm_ programme_an_open_and_secure_europe_en_1.pdf $>$.

EUROSTAT. Asylum quarterly report. December 9, 2015. Available at: < http:// ec.europa.eu/eurostat/statistics-explained/index.php/Asylum_quarterly_report>.

UNHCR. Mixed Migration Trends in Libya: Changing Dynamics and Protection Challenges. UNHCR, 2017. Available at: < http://www.unhcr.org/publications/ operations/595a02b44/mixed-migration-trends-libya-changing-dynamicsprotection-challenges.html>.

VALTOLINA Giovanni Giulio. Unaccompanied Minors in Italy. In CESAREO, Vincenzo (ed.). The Twenty-second Italian Report on Migrations 2016. Milan: McGraw-Hill, 2017 p. 69-76.

ZANFRINI Laura. How Europe can Benefit from Immigration-Related "Diversity" - A Policy Paper. Peace Economics, Peace Science and Public Policy, v. 22, n. 3, 2016, p. 295-326.

Received for publication in October 30 ${ }^{\text {th }}, 2017$ Accepted for publication in November 22 $2^{\text {nd }}, 2017$ Recebido para publicação em 30.10.2017 Aceito para publicação em 22.11.2017

ISSN impresso 1980-8585

ISSN eletrônico 2237-9843

http://dx.doi.org/10.1590/1980-85852503880005106 